\title{
Depressor action and vasorelaxation of methylene chloride fraction extracted from Rubus coreanum
}

Byung-Sik Yu' ${ }^{1}$, Mee-Sung Choi ${ }^{2}$ and Dong-Yoon Lim ${ }^{3 *}$

\begin{abstract}
Introduction: The present study was designed to examine whether methylene chloride $\left(\mathrm{CH}_{2} \mathrm{Cl}_{2}\right)$ fraction extracted from Rubus coreanum affects the contractility of the isolated thoracic aortic strips and blood pressure of normotensive rats.

Methods: One of the common carotid arteries or of the femoral arteries was catheterized with a polyethylene tubing. The tubing was connected to a pressure transducer, and pulse of the mean arterial blood pressure was recorded on a biological polygraph continuously.

Results: The $\mathrm{CH}_{2} \mathrm{Cl}_{2}$ fraction (range, 200 to $800 \mu \mathrm{g} / \mathrm{mL}$ ) significantly depressed both phenylephrine (PE, $10 \mu \mathrm{M}$ )- and high $\mathrm{K}^{+}(56 \mathrm{mM})$-induced contractile responses of the isolated thoracic aortic strips in a concentration-dependent fashion. In the simultaneous presence of $\mathrm{N}^{\omega}$-nitro-L-arginine methyl ester hydrochloride (L-NAME) (an inhibitor of nitric oxide [NO] synthase, $300 \mu \mathrm{M})$ and the $\mathrm{CH}_{2} \mathrm{Cl}_{2}$ fraction $(400 \mu \mathrm{g} / \mathrm{mL})$, both PE- and high $\mathrm{K}^{+}$-induced contractile responses were recovered to the significant level of the corresponding control response in comparison with inhibition of $\mathrm{CH}_{2} \mathrm{Cl}_{2}$ fraction treatment alone. Moreover, in the simultaneous presence of the $\mathrm{CH}_{2} \mathrm{Cl}_{2}$ fraction after pretreatment with $0.4 \%$ CHAPS (3-[(3-cholamidopropyl) dimethylammonio]-1-propane sulfonate), both PE- and high $\mathrm{K}^{+}$-induced contractile responses were recovered to the significant level of the corresponding control response compared to the inhibitory response of $\mathrm{CH}_{2} \mathrm{Cl}_{2}$ fraction treatment alone. Also, in anesthetized rats, the $\mathrm{CH}_{2} \mathrm{Cl}_{2}$ fraction (range, 0.3 to $3.0 \mathrm{mg} / \mathrm{kg}$ ) injected into a femoral vein dose-dependently produced depressor responses. This hypotensive action of the $\mathrm{CH}_{2} \mathrm{Cl}_{2}$ fraction was greatly inhibited after treatment with phentolamine $(1 \mathrm{mg} / \mathrm{kg})$, chlorisondamine $(1 \mathrm{mg} / \mathrm{kg})$, L-NAME ( $3 \mathrm{mg} / \mathrm{kg} / 30 \mathrm{~min}$ ), or sodium nitroprusside $\left(30 \mathrm{\mu g} / \mathrm{kg} / 30 \mathrm{~min}\right.$ ). Intravenous infusion of the $\mathrm{CH}_{2} \mathrm{Cl}_{2}$ fraction (range, 1.0 to $10.0 \mathrm{mg} / \mathrm{kg} / 30 \mathrm{~min}$ ) markedly inhibited norepinephrine-induced pressor responses.
\end{abstract}

Discussion: Taken together, these results demonstrate that the $\mathrm{CH}_{2} \mathrm{Cl}_{2}$ fraction causes vascular relaxation in the isolated rat thoracic aortic strips as well as hypotensive action in anesthetized rats. These vasorelaxation and hypotension of the $\mathrm{CH}_{2} \mathrm{Cl}_{2}$ fraction seem to be mediated at least by the increased $\mathrm{NO}$ production through the activation of $\mathrm{NO}$ synthase of the vascular endothelium and the inhibitory adrenergic modulation.

Keywords: Rubus coreanum (Bokboonja), Methylene chloride $\left(\mathrm{CH}_{2} \mathrm{Cl}_{2}\right)$ fraction, Vasorelaxation, Depressor action, Adrenergic $\mathrm{a}_{1}$-receptor blockade, Activation of $\mathrm{NO}$ synthase

\footnotetext{
* Correspondence: dylim@chosun.ac.kr

${ }^{3}$ Department of Pharmacology, School of Medicine, Chosun University, 309

Pilmun-daero, Dong-gu, Gwangju 501-759, Korea

Full list of author information is available at the end of the article
} 


\section{Introduction}

Previously, it has been reported that polyphenol compounds isolated from Rubus coreanum MIQUEL (PCRC) inhibit the secretory responses of catecholamines (CA) evoked by the stimulation of cholinergic (both muscarinic and nicotinic) receptors as well as by direct membrane depolarization from the isolated perfused adrenal gland of normotensive rats [1] and spontaneously hypertensive rats [2]. It seems that this inhibitory effect of PCRC is exerted by inhibiting both the $\mathrm{Ca}^{2+}$ influx into the rat adrenal medullary chromaffin cells and the uptake of $\mathrm{Ca}^{2+}$ into the cytoplasmic calcium store partly through the increased nitric oxide $(\mathrm{NO})$ production due to the activation of NO synthase $[1,2]$.

Polyphenols also act on other targets involved in the metabolism of mammalian cells, including $\mathrm{NO}$, which by itself regulates hemostasis [3], thrombus development [4], and vascular tone [5,6]. The properties of NO may therefore explain, at least in part, the beneficial effects of plant polyphenols. Several authors have reported that extracts from grapes and wine induce endotheliumdependent relaxation via enhanced generation and/or increased biological activity of NO leading to the elevation of cyclic guanosine monophosphate (cGMP) levels [7]. The critical step for the activation of NO synthase in endothelial cells is the increase in $\mathrm{Ca}^{2+}$ concentration leading to the production of $\mathrm{NO}$ and the subsequent endothelium-dependent vasorelaxation [8]. The biological activity of NO can be effectively increased by the scavengers of oxygen free radicals [9].

As aforementioned, there are many reports about the effects of red wine on the cardiovascular system. Despite these studies, there are so far few reports on in vitro functional effects of fractions isolated from Bokboonja wine on the cardiovascular system. Therefore, the aim of the present study was to investigate the effects of some fractions isolated from Bokboonja wine on blood pressure and on the contractility of the isolated rat thoracic aorta and to clarify their mechanism of action in order to supply information for isolation of active antihypertensive components.

\section{Methods}

\section{Experimental procedure}

All procedures involving animal experiment were approved by the Committee of Experimental Animals, Chosun University School of Medicine.

\section{Vasorelaxation}

Mature male Sprague-Dawley rats (purchased from DAMOOL SCIENCE; International Customer Service, Seoul, Korea), weighing 200 to 300 g, were used in the experiment. The animals were housed individually in separate cages, and food (Cheil Animal Chow, Seoul, Korea) and tap water were allowed ad libitum for at least a week to adapt to experimental circumstances. On the day of the experiment, a rat was anesthetized with thiopental sodium (50 mg/kg) intraperitoneally and tied in supine position on a fixing panel.

(1). Isolation of thoracic aortic strips: The thorax was opened by a midline incision, and the heart and surrounding area were exposed by placing three hook retractors. The heart and a portion of the lung were not removed but pushed over to the right side and covered by saline-soaked gauze pads in order to obtain enough working space for isolating the thoracic aortic vessel. The aorta was isolated from the proximal part of the heart to the vicinity of the liver and immediately immersed in cold Krebs solution. The blood within the aorta was rapidly removed. The aorta was cut into the ring of 4-to 5-mm length.

(2). Recording of mechanical activity: The ring segment of the aorta was mounted in a muscle bath by sliding the ring over two parallel stainless steel hooks $(0.15$ $\mathrm{mm}$ in diameter). The lower hook was fixed at the bottom of the bath and the upper was connected to an isometric transducer (Grass FT. 03). The signal from the transducer was displayed on a polygraph (Grass Instruments Model 79; Grass Instrument Co., Quincy, MA, USA). The volume of the bath was 25 $\mathrm{mL}$ and the bath solution was saturated with $95 \% \mathrm{O}_{2}$ and $5 \% \mathrm{CO}_{2}$ at $37^{\circ} \mathrm{C}$. The composition $(\mathrm{mM})$ of Krebs was as follows: $\mathrm{NaCl}, 118.4 ; \mathrm{KCl}, 4.7 ; \mathrm{CaCl}_{2}$, 2.5; $\mathrm{MgCl}_{2}, 1.18 ; \mathrm{NaHCO}_{3}, 25 ; \mathrm{KH}_{2} \mathrm{PO}_{4}, 1.2$; and glucose, 11.7. The final $\mathrm{pH}$ of the solution was maintained at 7.4 to 7.5 . During equilibration period of $2 \mathrm{~h}$, the resting tension was adjusted to $0.5 \mathrm{~g}$. After the equilibration period, the ring was challenged with $35 \mathrm{mM} \mathrm{KCl}$ twice, and if it responded with contraction, the proper experiment was started. Vasoconstrictors were administered into the bath in order to obtain dose-response curves. In the subsequent experiments, under the presence of extracts of Rubus coreanum, some vasoconstrictors were administered, respectively. The data were expressed as percentage of the control tension.

(3). Removal of endothelium: A solution containing 0.4\% 3-[(3-cholamidopropyl) dimethylammonio]1 -propane sulfonate (CHAPS) was perfused for 30 $\mathrm{s}$ to remove the endothelium [10], followed by washout with a drug-free solution. The effect of CHAPS was confirmed by the absence of a flow increase due to $10^{-6} \mathrm{M}$ acetylcholine and the presence of a response to $10^{-6} \mathrm{M}$ sodium nitroprusside before the experiments were started. The vasoconstrictor-induced response of non-treated (control) and CHAPS-treated preparations was compared in parallel. 


\section{Blood pressure}

(1). Preparation for measurement of arterial pressure: The animal was tied in supine position on a fixing panel to insert a T-formed cannula into the trachea for securing free air passage. The rectal temperature was maintained at $37^{\circ} \mathrm{C}$ to $38^{\circ} \mathrm{C}$ by a thermostatically controlling blanket and heating lamp throughout the course of the experiment.

(2). Measurement of blood pressure: In order to observe the change of arterial pressure, one of the common carotid arteries or of the femoral arteries was catheterized with a polyethylene tubing (outside diameter [od], $0.5 \mathrm{~mm}$ ). The tubing was connected to a pressure transducer (Gould Co., Quincy, MA, USA), and pulse of the mean arterial blood pressure was recorded on a biological polygraph continuously (Grass Co.). The chart speed was adjusted to $2 \mathrm{~cm} / \mathrm{min}$. The artery tubing was filled with heparin solution (400 IU) to prevent the blood coagulation during the experiment. Another cannulation with a polyethylene tubing (od, $0.3 \mathrm{~mm}$ ) was made into a femoral vein for the administration of drugs and supplemental anesthetic agents as needed to maintain light surgical anesthesia. Each rat was left undisturbed for at least $30 \mathrm{~min}$ after completion of the operative procedures to permit cardiovascular parameters to be stabilized, and drugs under investigation were administered at intervals of $60 \mathrm{~min}$.

\section{Fractionation of Rubus coreanum}

Fractionation of Rubus coreanum extract was made from a 1-year-old wine brewed from Rubus coreanum MIQUEL at the Research Institute of Bokboonja, Gochang County, Cheollabukdo Province, Korea, as shown in Figure 1A: wine of Rubus coreanum was concentrated in a vacuum. And then, it was extracted with methylene chloride $\left(\mathrm{CH}_{2} \mathrm{Cl}_{2}\right)$ followed by extraction with ethylacetate (EtOAc) and $\mathrm{N}$ butanol. These fractions were concentrated by vacuum, evaporated and atomized, and lyophilized by freeze dryer (Coldvac-80; Hanil R\&D, Seoul, Korea). Extract of $2.095 \mathrm{~g}$ $\mathrm{CH}_{2} \mathrm{Cl}_{2}, 10.968 \mathrm{~g}$ EtOAc, and $9.057 \mathrm{~g} \mathrm{~N}$-butanol was obtained from $6 \mathrm{~L}$ Bokboonja wine, respectively. The working solution of these extracts was prepared by dissolving in $0.9 \% \mathrm{NaCl}$ solution or dimethyl sulfoxide (DMSO) on the day of each experiment and filtered before administration and diluted appropriately with Krebs-bicarbonate solution (final concentration of alcohol was less than $0.1 \%$ ).

\section{Statistical analysis}

The statistical difference between the control and the pretreated groups was determined by the Student $t$ test and analysis of variance test. A $p$ value of less than 0.05 was considered to represent statistically significant changes unless specifically noted in the text. Values given in the text refer to means and the standard errors of the mean. The statistical analysis of the experimental results was made by a computer program described by Tallarida and Murray [11].

\section{Drugs and their sources}

The following drugs were used: phenylephrine (PE) hydrochloride, potassium chloride, $\mathrm{N}^{\omega}$-nitro-L-arginine methyl ester hydrochloride (L-NAME), CHAPS, norepinephrine bitartrate (Sigma-Aldrich Chemical Co., St. Louis, MO, USA), chlorisondamine chloride, phentolamine mesylate (Ciba Pharmaceutical Co., Summit, NJ, USA), thiopental sodium, and heparin sodium (Daehan Choongwae Pharm. Co., Seoul, Korea). Drugs were dissolved in distilled water (stock) and added to the normal Krebs solution as required except the $\mathrm{CH}_{2} \mathrm{Cl}_{2}$ fraction, which were dissolved in DMSO and diluted appropriately with Krebs-bicarbonate solution (final concentration of DMSO was less than $0.1 \%$ ). Concentrations of all drugs except the $\mathrm{CH}_{2} \mathrm{Cl}_{2}$ fraction used were expressed in terms of molar base.

\section{Results}

\section{Effects of four fractions extracted from Rubus coreanum} on PE-induced contractile responses in the thoracic aortic strips of normotensive rats

The effects of four fractions extracted from Rubus coreanum on PE-induced contractile responses in the rat aorta with an intact endothelium were examined. In the present study, the $\mathrm{CH}_{2} \mathrm{Cl}_{2}$ fraction itself did not produce any effect on the resting tension in the aortic strips with an intact endothelium isolated from rats (data not shown). In a previous study, it has been found that PCRC causes vascular relaxation in the isolated aortic strips of spontaneously hypertensive rats (SHRs) at least partly by the increased NO production through the activation of NO synthase of the vascular endothelium, but not through the activation of cyclooxygenase [12]. Therefore, it was attempted to examine the effects of four fractions (EtOAc, $\mathrm{CH}_{2} \mathrm{Cl}_{2}, \mathrm{~N}$-butanol $[\mathrm{BuOH}]$, and water $\left[\mathrm{H}_{2} \mathrm{O}\right]$ ) isolated from Rubus coreanum $\mathrm{M}$. on PEinduced contractile responses in the isolated rat aortic strips. As shown in Figure $1 \mathrm{~B}$, in the presence of the $\mathrm{CH}_{2} \mathrm{Cl}_{2}$ fraction $(400 \mu \mathrm{g} / \mathrm{mL})$, EtOAc fraction $(400 \mu \mathrm{g} / \mathrm{mL}), \mathrm{BuOH}$ fraction $(400 \mu \mathrm{g} / \mathrm{mL})$, and $\mathrm{H}_{2} \mathrm{O}$ fraction $(400 \mu \mathrm{g} / \mathrm{mL}) 5 \mathrm{~min}$ before addition of $\mathrm{PE}$, the contractile responses of $\mathrm{PE}$ $\left(10^{-5} \mathrm{M}\right)$ were significantly reduced to $50 \% \pm 1 \%(p<0.01$, $n=6), 58 \% \pm 11 \%(p<0.01, n=6), 90 \% \pm 18 \%(p<0.01$, $n=8)$, and $78 \% \pm 2 \%(p<0.05, n=6)$ of the corresponding control response $(1.6 \pm 0.1 \mathrm{~g})$, respectively. Based on these results, for the PE-induced contractile response, the following rank order of inhibitory potency was obtained: $\mathrm{CH}_{2} \mathrm{Cl}_{2}$ fraction $>$ EtOAc fraction $>\mathrm{H}_{2} \mathrm{O}$ fraction $>\mathrm{BuOH}$ fraction. Therefore, in all subsequent experiments, the $\mathrm{CH}_{2} \mathrm{Cl}_{2}$ fraction $(400 \mu \mathrm{g} / \mathrm{mL})$ only was used. 


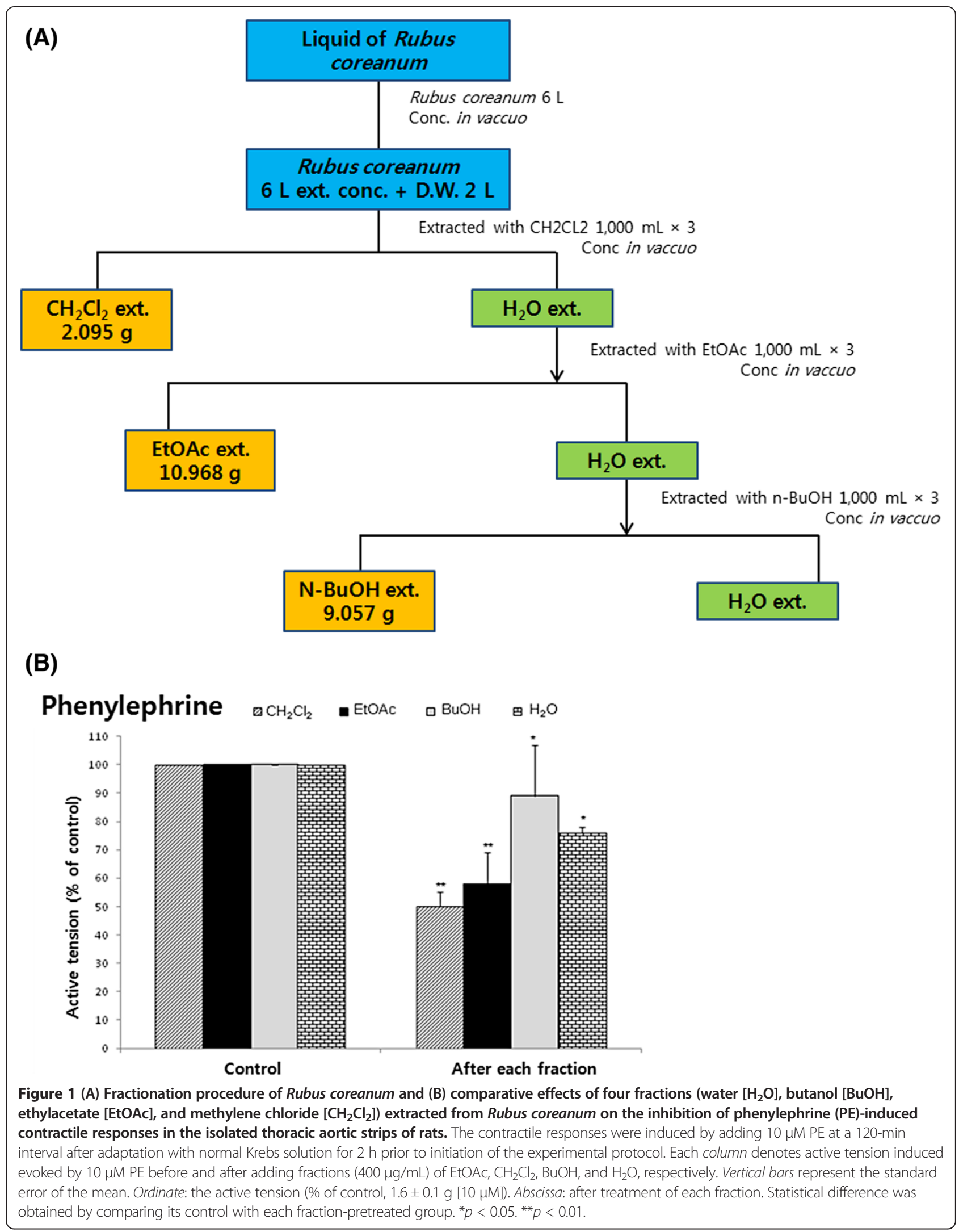


Effects of the $\mathrm{CH}_{2} \mathrm{Cl}_{2}$ fraction isolated from Rubus coreanum on contractile responses induced by PE and high $\mathrm{K}^{+}$in the thoracic aortic strips of normotensive rats $\mathrm{PE}$ is a selective agonist of adrenergic $\alpha_{1}$-receptors, which exhibits vasoconstriction. To establish the inhibitory effect of the $\mathrm{CH}_{2} \mathrm{Cl}_{2}$ fraction on $\mathrm{PE}\left(10^{-5} \mathrm{M}\right)$-induced contractile responses, in the presence of the $\mathrm{CH}_{2} \mathrm{Cl}_{2}$ fraction at $400 \mu \mathrm{g} /$ $\mathrm{mL} 5 \mathrm{~min}$ before addition of $\mathrm{PE}$, the contractile response of
PE $\left(10^{-5} \mathrm{M}\right)$ was greatly reduced to $50 \% \pm 5 \%(p<0.01$, $n=6)$ of the corresponding control response $(1.8 \pm 0.2 \mathrm{~g})$ (Figure 2).

High $\mathrm{K}^{+}$exerts two distinct effects on cells: (1) depolarization of the cell membrane and (2) depolarizationinduced influx of calcium via voltage-dependent calcium channels [13]. When added to the bath, high potassium at $5.6 \times 10^{-2} \mathrm{M}$, which is a membrane-depolarizing agent,

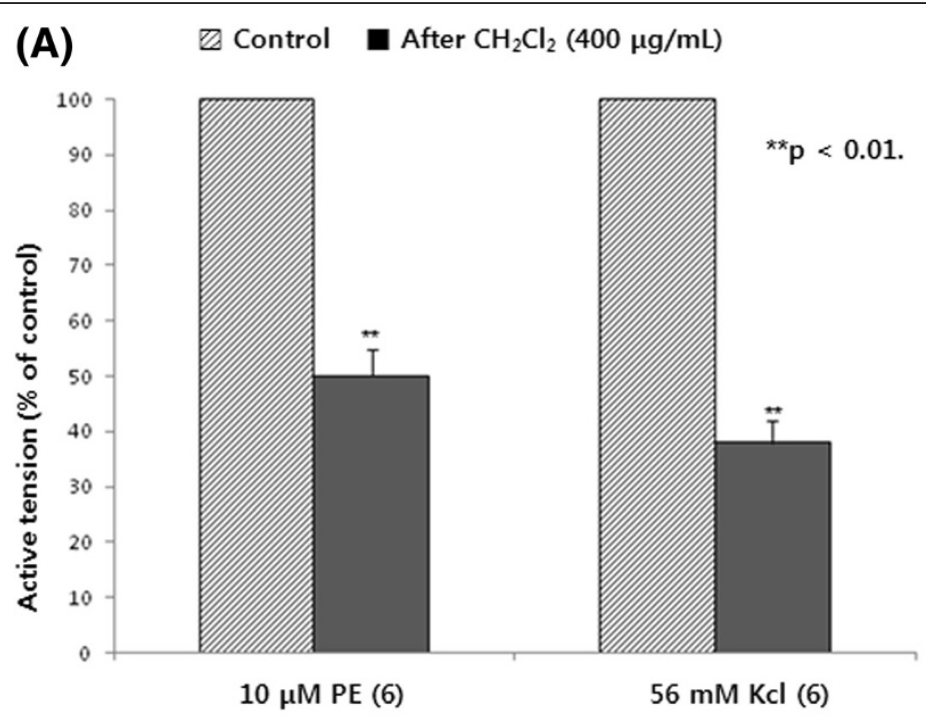

(B)
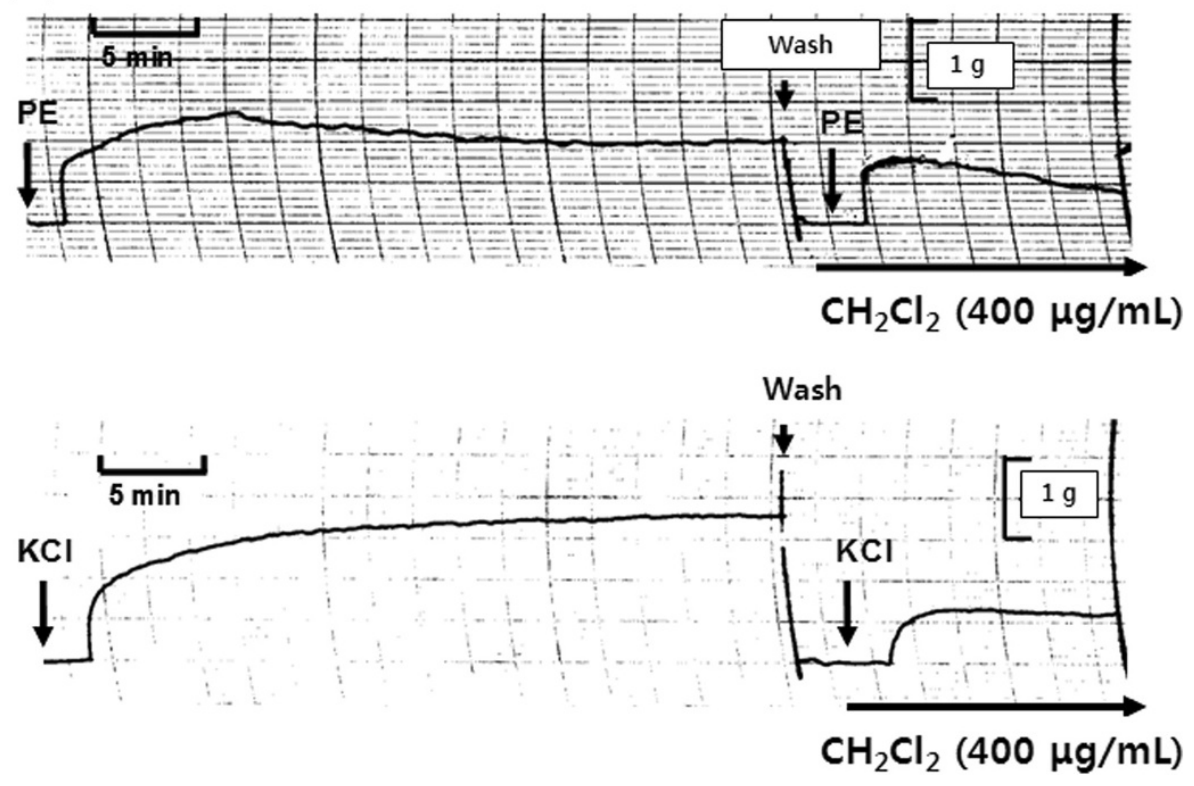

Figure $2(\mathrm{~A})$ Influence of methylene chloride $\left(\mathrm{CH}_{2} \mathrm{Cl}_{2}\right)$ fraction on phenylephrine (PE)- and high potassium (KCl)-induced contractile responses and (B) the typical tracing showing the effect of $\mathrm{CH}_{2} \mathrm{Cl}_{2}$ fraction on PE- and high potassium (KCl)-induced contractile response in the isolated rat aortic strips. Black column and brick column denote active tension induced evoked by $10 \mu \mathrm{M}$ PE before and after adding $400 \mathrm{\mu g} / \mathrm{mL}$ of $\mathrm{CH}_{2} \mathrm{Cl}_{2}$ fraction, respectively. Other methods are the same as in Figure 1. ${ }^{*} p<0.01$. (A) Left: PE-induced contractile response (control); right: $\mathrm{PE}$-induced contractile response in the presence of $\mathrm{CH}_{2} \mathrm{Cl}_{2}$ fraction $(400 \mu \mathrm{g} / \mathrm{mL})$. (B) Left: $\mathrm{KCl}$-induced contractile response (control); right: $\mathrm{KCl}$-induced contractile response in the presence of $\mathrm{CH}_{2} \mathrm{Cl}_{2}$ fraction $(400 \mu \mathrm{g} / \mathrm{mL})$. At arrow marks, the indicated doses of PE $(10 \mu \mathrm{M})$ and $\mathrm{KCl}(56 \mathrm{mM})$ were added into the bath, respectively. The chart speed was $5 \mathrm{~mm} / \mathrm{min}$. 
caused an increase in aortic contraction $(2.4 \pm 0.2 \mathrm{~g})$. As shown in Figure 2, high potassium $\left(5.6 \times 10^{-2} \mathrm{M}\right)$-induced contractile response after preloading with $400 \mu \mathrm{g} / \mathrm{mL}$ of the $\mathrm{CH}_{2} \mathrm{Cl}_{2}$ fraction $5 \mathrm{~min}$ before high potassium was significantly reduced to $62 \% \pm 8 \%(p<0.01, n=6)$ of the corresponding control response $(2.4 \pm 0.2 \mathrm{~g})$.

Influence of the $\mathrm{CH}_{2} \mathrm{Cl}_{2}$ fraction plus L-NAME on the contractile responses evoked by $\mathrm{PE}$ and high potassium in the thoracic aortic strips of normotensive rats

In a previous study, it has been demonstrated that PCRC inhibits the CA secretion evoked by cholinergic stimulation and direct membrane depolarization from the perfused rat adrenal medulla, which was blocked in the presence of LNAME, a NO synthase inhibitor [2]. These results suggest that PCRC can inhibit the CA release at least partly through the activation of NO synthase in the rat adrenal medulla. Therefore, in the presence of L-NAME, it was likely interesting to compare the effects of the $\mathrm{CH}_{2} \mathrm{Cl}_{2}$ fraction on the contractile responses induced by high potassium and PE.

In the simultaneous presence of $\mathrm{CH}_{2} \mathrm{Cl}_{2}$ fraction $(400 \mu \mathrm{g} / \mathrm{mL})$ and L-NAME $(300 \mu \mathrm{M})$, the aortic contractile response evoked by $\mathrm{PE}\left(10^{-5} \mathrm{M}\right)$ was recovered to $94 \% \pm 11 \%(p<0.05, n=10)$ of the control in comparison with the inhibitory response of $\mathrm{CH}_{2} \mathrm{Cl}_{2}$ fraction treatment alone $(50 \% \pm 5 \%)$ from the resting tension level as shown in Figure 3. High potassium $\left(5.6 \times 10^{-2} \mathrm{M}\right)$ induced contractile response in the simultaneous presence of $\mathrm{CH}_{2} \mathrm{Cl}_{2}$ fraction $(400 \mu \mathrm{g} / \mathrm{mL})$ and L-NAME $(300 \mu \mathrm{M})$ was recovered to $54 \% \pm 4 \%(p<0.05, n=6)$ of the corresponding control compared with the inhibitory response of $\mathrm{CH}_{2} \mathrm{Cl}_{2}$ fraction treatment alone $(38 \% \pm 4 \%)$ from the resting tension level (Figure 3).

Influence of the $\mathrm{CH}_{2} \mathrm{Cl}_{2}$ fraction plus CHAPS on contractile responses induced by $\mathrm{PE}$ and high potassium in the thoracic aortic strips of normotensive rats

As shown in Figure $3, \mathrm{CH}_{2} \mathrm{Cl}_{2}$ fraction-induced vasorelaxation was markedly blocked in the presence of $\mathrm{L}$ NAME, a NO synthase inhibitor. Therefore, it is likely interesting to examine the effects of CHAPS, a detergent which suppresses endothelial function [10], on $\mathrm{CH}_{2} \mathrm{Cl}_{2}$ fraction-induced inhibitory responses to the contractile active tension evoked by high potassium and $\mathrm{PE}$.

In the presence of the $\mathrm{CH}_{2} \mathrm{Cl}_{2}$ fraction $(400 \mu \mathrm{g} / \mathrm{mL})$ after pretreatment with $0.4 \%$ CHAPS, the aortic contractile response evoked by PE $\left(10^{-5} \mathrm{M}\right)$ was recovered to $67 \% \pm 13 \%(p<0.01, n=6)$ of the corresponding control compared with the inhibitory response of $\mathrm{CH}_{2} \mathrm{Cl}_{2}$ fraction treatment alone $(38 \% \pm 4 \%)$ from the resting tension level, as shown in Figure 4. High potassium $\left(5.6 \times 10^{-2} \mathrm{M}\right)$-induced contractile response in the simultaneous presence of the $\mathrm{CH}_{2} \mathrm{Cl}_{2}$ fraction $(400 \mu \mathrm{g} / \mathrm{mL})$ after pretreatment with CHAPS was recovered to $67 \% \pm 13 \%$ ( $p$ $<0.01, n=6$ ) of the corresponding control compared with the inhibitory response of $\mathrm{CH}_{2} \mathrm{Cl}_{2}$ fraction treatment alone $(38 \% \pm 4 \%)$ from the resting tension level (Figure 4).

\section{Effects of intravenous $\mathrm{CH}_{2} \mathrm{Cl}_{2}$ fraction on blood pressure in the anesthetized normotensive rats}

All rats used in this study were allowed to be stabilized at least for $60 \mathrm{~min}$ before experimental protocols were initiated. When cardiovascular parameters were stabilized, the $\mathrm{CH}_{2} \mathrm{Cl}_{2}$ fraction (range, 0.3 to $3.0 \mathrm{mg} / \mathrm{kg}$ ) was given into a femoral vein of the normotensive rats anesthetized with thiopental sodium and urethane. The $\mathrm{CH}_{2} \mathrm{Cl}_{2}$ fraction produced a dose-related and potent fall in arterial blood pressure. However, an equivalent volume of $0.9 \%$ saline given into a femoral vein did not produce any changes in blood pressure of the normotensive rats. As shown in Figure 5, intravenous $0.3 \mathrm{mg}$ of $\mathrm{CH}_{2} \mathrm{Cl}_{2}$ fraction induced a fall in mean arterial pressure by $9.1 \pm 1.1 \mathrm{~mm} \mathrm{Hg}$ from the original baseline of $122.2 \pm$ $4.0 \mathrm{~mm} \mathrm{Hg}$, but increasing doses of the $\mathrm{CH}_{2} \mathrm{Cl}_{2}$ fraction to 1.0 and $3.0 \mathrm{mg} / \mathrm{kg}$ intravenously (i.v.) showed decreased mean arterial pressures of $15.0 \pm 1.8$ and $25.3 \pm 2.7 \mathrm{~mm}$ $\mathrm{Hg}$, respectively, from the preinjection level of the baseline from ten rats. All of the above experimental results were statistically significant from the corresponding preinjection values $(p<0.01)$.

Influence of phentolamine, chlorisondamine, L-NAME, and sodium nitroprusside on the $\mathrm{CH}_{2} \mathrm{Cl}_{2}$ fraction-induced depressor action

In eight rats, in order to examine the relationship between adrenergic $\alpha$-receptors and $\mathrm{CH}_{2} \mathrm{Cl}_{2}$ fractioninduced depressor action, phentolamine $(1.0 \mathrm{mg} / \mathrm{kg})$ was given i.v. after obtaining the control responses of the intravenous $\mathrm{CH}_{2} \mathrm{Cl}_{2}$ fraction. In the presence of a phentolamine effect, depressor response induced by the intravenous $\mathrm{CH}_{2} \mathrm{Cl}_{2}$ fraction $(1.0 \mathrm{mg} / \mathrm{kg})$ was greatly depressed to $-5.8 \pm 1.7 \mathrm{~mm} \mathrm{Hg}(p<0.01)$ from the preinjection level of the baseline as compared with the control depressor response $(-19.1 \pm 2.9 \mathrm{~mm} \mathrm{Hg})$ as shown in Figures 6 and 7A. Chlorisondamine $(1.0 \mathrm{mg} / \mathrm{kg})$, an autonomic ganglionic blocking agent, was given slowly into a femoral vein. Following the administration of chlorisondamine, the baseline of blood pressure was reduced from $119.2 \pm 4.1$ to $70.2 \pm 3.9 \mathrm{~mm} \mathrm{Hg}$. In ten rats, intravenous $\mathrm{CH}_{2} \mathrm{Cl}_{2}$ fraction $(1.0 \mathrm{mg} / \mathrm{kg})$-induced depressor response after chlorisondamine treatment was markedly inhibited by $-0.4 \pm 0.2 \mathrm{~mm} \mathrm{Hg}(p<0.01)$ as compared with the control depressor response $(-19.0 \pm$ $3.3 \mathrm{~mm} \mathrm{Hg}$ ), as shown in Figures 6 and 7B. Intravenous infusion of L-NAME (3 $\mathrm{mg} / \mathrm{kg} / 30 \mathrm{~min}$ ), an inhibitor of NO synthase, into a femoral vein resulted in a significant decrease by $-4.7 \pm 0.8 \mathrm{~mm} \mathrm{Hg}(p<0.01, n=20)$ in the 
(A)

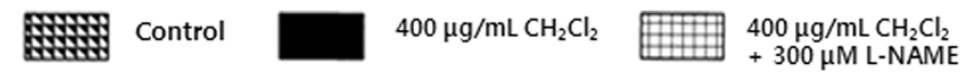

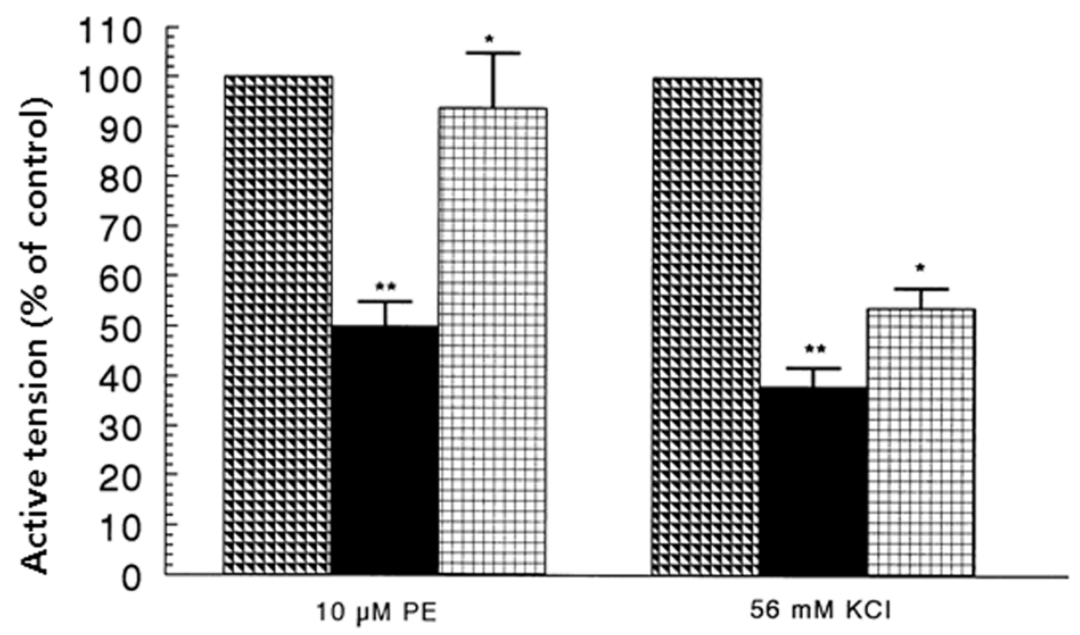

(B)
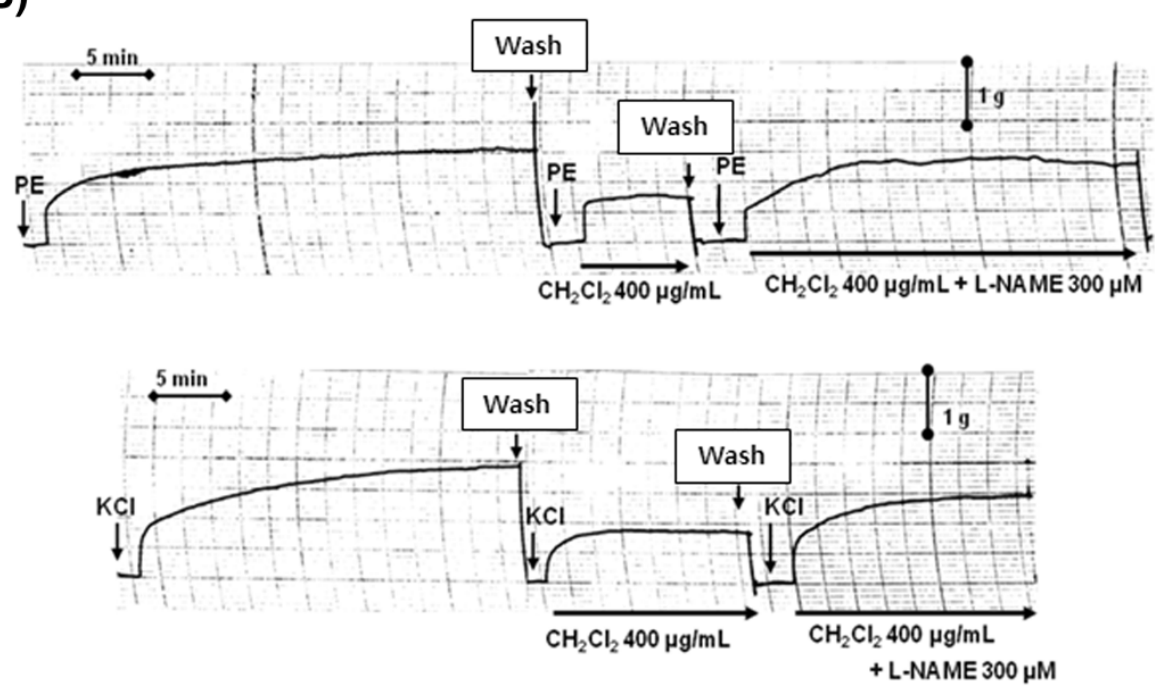

Figure $3(\mathrm{~A})$ Influence of methylene chloride $\left(\mathrm{CH}_{2} \mathrm{Cl}_{2}\right)$ fraction plus $\mathrm{N}^{\omega}$-nitro-L-arginine methyl ester hydrochloride (L-NAME) on the contractile responses evoked by phenylephrine (PE) and high potassium $(\mathrm{KCl})$ and $(\mathrm{B})$ the typical tracing showing the effect of $\mathrm{CH}_{2} \mathrm{Cl}_{2}$ fraction plus L-NAME on (upper panel) PE- and (lower panel) high potassium-induced contractile response in the isolated rat aortic strips. Statistical difference was obtained by comparing the control with the $\mathrm{CH}_{2} \mathrm{Cl}_{2}$ fraction-pretreated group or $\mathrm{CH}_{2} \mathrm{Cl}_{2}$ fraction ( $400 \mathrm{\mu g} / \mathrm{mL}$ ) plus L-NAME $(300 \mu \mathrm{M})$. Other methods are the same as in Figure 2. ${ }^{*} p<0.05 .{ }^{*} p<0.01$. (A) Left: PE-induced contractile response (control); middle: PE-induced contractile response in the presence of $\mathrm{CH}_{2} \mathrm{Cl}_{2}$ fraction $(400 \mu \mathrm{g} / \mathrm{mL})$; right: $\mathrm{PE}$-induced contractile response in the presence of $\mathrm{CH}_{2} \mathrm{Cl}_{2}$ fraction $(400 \mu \mathrm{g} / \mathrm{mL})$ plus L-NAME $(300 \mu \mathrm{M})$. (B) Left: KCl-induced contractile response (control); middle: $\mathrm{KCl}$-induced contractile response in the presence of $\mathrm{CH}_{2} \mathrm{Cl}_{2}$ fraction $(400 \mu \mathrm{g} / \mathrm{mL})$; right: $\mathrm{KCl}$-induced contractile response in the presence of $\mathrm{CH}_{2} \mathrm{Cl}_{2}$ fraction $(400 \mu \mathrm{g} / \mathrm{mL})$ plus L-NAME $(300 \mu M)$.

blood pressure as compared with the control depressor response $(-15.4 \pm 1.5 \mathrm{~mm} \mathrm{Hg})$, as shown in Figures 6 and 8A. In six rats, in order to examine the relationship between $\mathrm{NO}$ and $\mathrm{CH}_{2} \mathrm{Cl}_{2}$ fraction-induced depressor action, sodium nitroprusside $(30 \mu \mathrm{g} / \mathrm{kg} / 30 \mathrm{~min})$ was infused i.v. after obtaining the control responses of the intravenous $\mathrm{CH}_{2} \mathrm{Cl}_{2}$ fraction. In the presence of a sodium nitroprusside effect, depressor response induced by the intravenous $\mathrm{CH}_{2} \mathrm{Cl}_{2}$ fraction $(1.0 \mathrm{mg} / \mathrm{kg})$ was greatly depressed to $-9.3 \pm 3.5 \mathrm{~mm} \mathrm{Hg}(p<0.01)$ as 


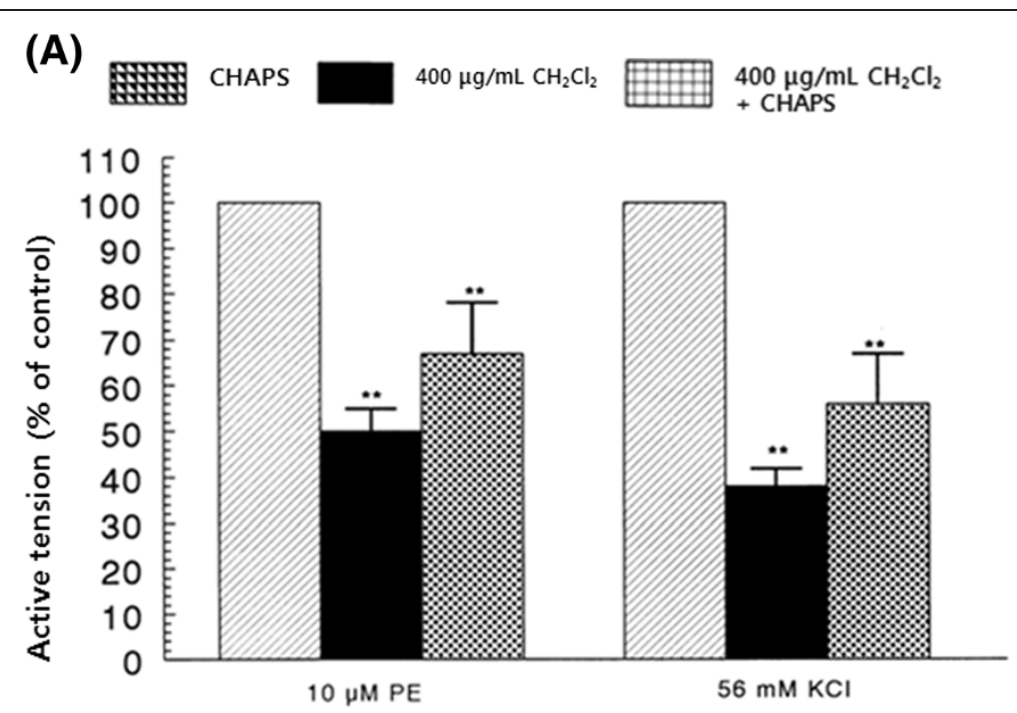

(B)
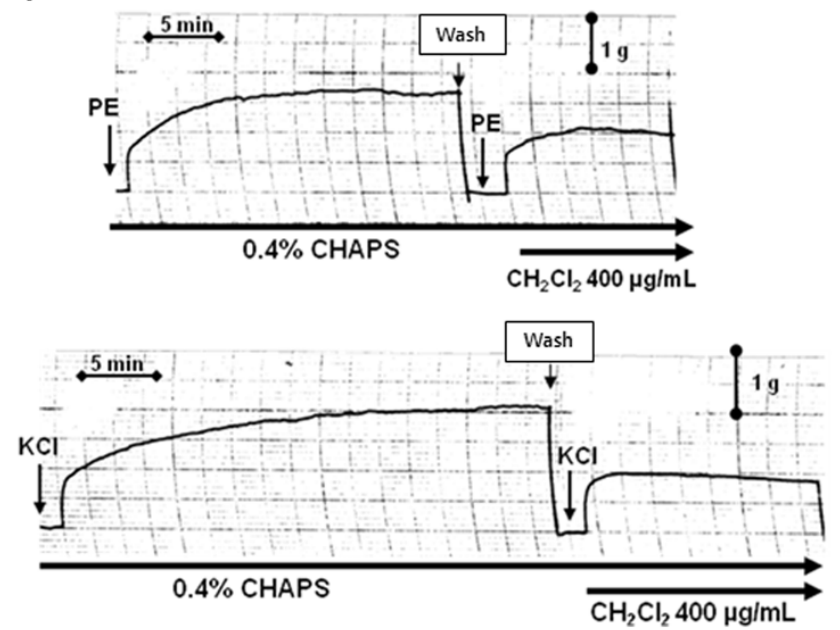

Figure 4 (A) Influence of 3-[(3-cholamidopropyl) dimethylammonio]-1-propane sulfonate (CHAPS) plus methylene $\mathrm{chloride}\left(\mathrm{CH}_{2} \mathrm{Cl}_{2}\right)$ fraction on contractile responses induced by phenylephrine $(\mathrm{PE})$ and high potassium $(\mathrm{KCl})$ and $(\mathrm{B})$ the representative tracing of $\mathrm{CHAPS}$ plus $\mathrm{CH}_{2} \mathrm{Cl}_{2}$ fraction effect on contractile responses induced by $\mathrm{PE}$ and high potassium in the isolated rat aortic strips. Other methods are the same as in Figure 3. ${ }^{* *} p<0.01$. At arrow marks, PE $(10 \mu \mathrm{M})$ and $\mathrm{KCl}(56 \mathrm{mM})$ were added into CHAPS-pretreated aortic strips. (A) PE-induced contractile response after $\mathrm{CH}_{2} \mathrm{Cl}_{2}$ fraction $(400 \mu \mathrm{g} / \mathrm{mL})$ treatment in a CHAPS-pretreated aortic strip. (B) High $\mathrm{KCl}$-induced contractile response after $\mathrm{CH}_{2} \mathrm{Cl}_{2}$ fraction $(400 \mathrm{\mu g} / \mathrm{mL}$ ) treatment in a CHAPS-pretreated aortic strip. The chart speed was $5 \mathrm{~mm} / \mathrm{min}$.

compared with the control depressor response $(-22.3 \pm$ $4.3 \mathrm{~mm} \mathrm{Hg}$ ) as shown in Figures 6 and 8B.

\section{Influence of the intravenous $\mathrm{CH}_{2} \mathrm{Cl}_{2}$ fraction on norepinephrine-evoked pressor responses in the anesthetized rats}

As shown in Figures 2, 6, and 7, the $\mathrm{CH}_{2} \mathrm{Cl}_{2}$ fraction greatly inhibited $\mathrm{PE}$-induced contractile response of the aortic strip of normotensive rats, and also, $\mathrm{CH}_{2} \mathrm{Cl}_{2}$ fraction-induced depressor responses were significantly reduced by phentolamine and chlorisondamine; this suggests that the $\mathrm{CH}_{2} \mathrm{Cl}_{2}$ fraction might cause hypotension through the blockade of peripheral adrenergic $\alpha$ - receptors. It is also of interest to examine the effect of the $\mathrm{CH}_{2} \mathrm{Cl}_{2}$ fraction on norepinephrine-evoked pressor responses. When cardiovascular parameters were stabilized for $30 \mathrm{~min}$ before the experimental protocols were initiated, the administration of physiological saline solution in a volume of $0.2 \mathrm{~mL}$ into a femoral vein did not cause any changes in arterial blood pressure. Then, it was tried to test the effect of the $\mathrm{CH}_{2} \mathrm{Cl}_{2}$ fraction on norepinephrine-induced hypertensive responses in the anesthetized rats.

In nine rats, as shown in Figure 9, norepinephrine at doses of $0.3,1.0$, and $3.0 \mu \mathrm{g} / \mathrm{kg}$ i.v. caused dose-dependent pressor responses of $8.9 \pm 0.8,16.5 \pm 1.7$, and $29.6 \pm 2.6 \mathrm{~mm}$ 


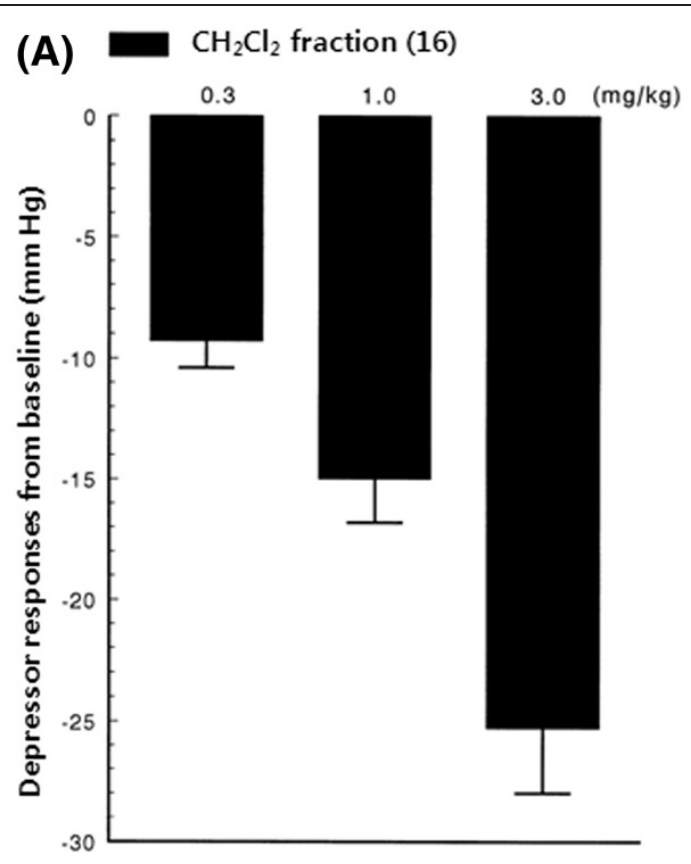

(B)

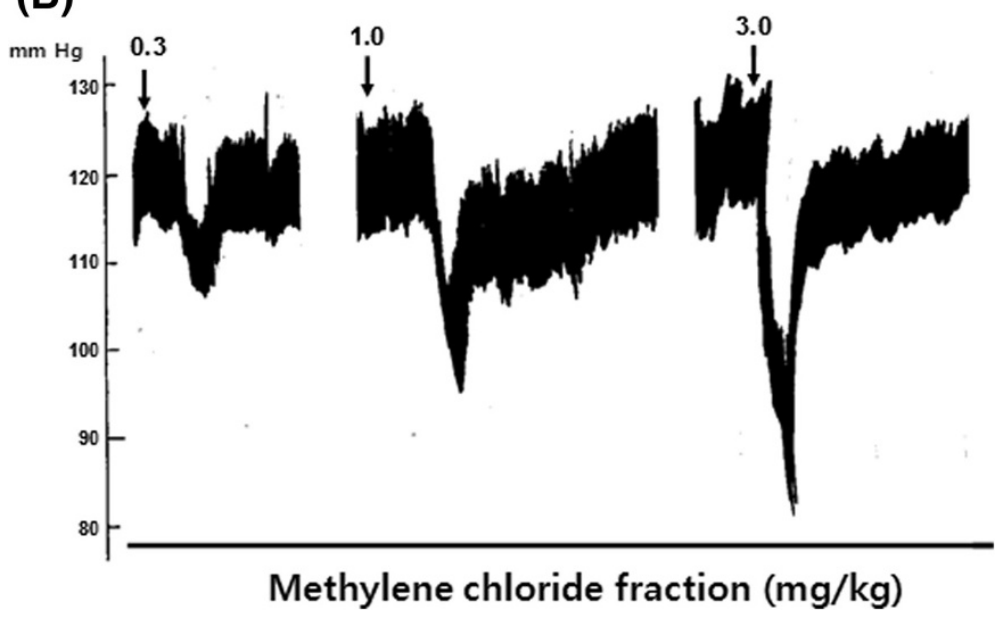

Figure 5 (A) Dose-dependent hypotensive effects of methylene chloride $\left(\mathrm{CH}_{2} \mathrm{Cl}_{2}\right)$ fraction and (B) the typical tracings of $\mathrm{CH}_{2} \mathrm{Cl}_{2}$ fraction-induced hypotensive action in an anesthetized rat. $\mathrm{CH}_{2} \mathrm{Cl}_{2}$ fraction $(0.3,1.0$, and $3.0 \mathrm{mg} / \mathrm{kg}$, respectively) was administered into a femoral vein. Arterial blood pressure from preinjection level was expressed in millimeters of mercury. $\mathrm{CH}_{2} \mathrm{Cl}_{2}$ fraction at the indicated doses $(0.3,1.0$, and $3.0 \mathrm{mg} / \mathrm{kg})$ was injected intravenously at the arrow marks.

$\mathrm{Hg}$ from the original baseline $(122.1 \pm 5.0 \mathrm{~mm} \mathrm{Hg})$, respectively. After infusion of the $\mathrm{CH}_{2} \mathrm{Cl}_{2}$ fraction with a rate of $3.0 \mathrm{mg} / \mathrm{kg} / 30 \mathrm{~min}$, hypertensive responses of norepinephrine at doses of $0.3,1.0$, and $3.0 \mu \mathrm{g} / \mathrm{kg}$ were inhibited maximally to $4.9 \pm 0.6 \mathrm{~mm} \mathrm{Hg}(p<0.01), 10.8 \pm 1.2 \mathrm{~mm} \mathrm{Hg}$ $(p<0.01)$, and $20.3 \pm 2.5 \mathrm{~mm} \mathrm{Hg}(p<0.01)$ of control responses at the above same doses, respectively.

\section{Discussion}

The present experimental results demonstrate that the $\mathrm{CH}_{2} \mathrm{Cl}_{2}$ fraction causes depressor action as well as vasorelaxation in the isolated aortic strips of normotensive rats at least partly by the increased NO production through the activation of NO synthase of the vascular endothelium.

In support of this idea, it has been demonstrated that PCRC inhibits the CA secretory responses evoked by stimulation of cholinergic (both muscarinic and nicotinic) receptors as well as by direct membrane depolarization from the isolated perfused adrenal gland of the normotensive rats [1] and SHRs [14]. It seems that this inhibitory effect of PCRC is exerted by inhibiting both the $\mathrm{Ca}^{2+}$ influx into the rat adrenal medullary chromaffin cells and the uptake of $\mathrm{Ca}^{2+}$ into the cytoplasmic calcium store partly 


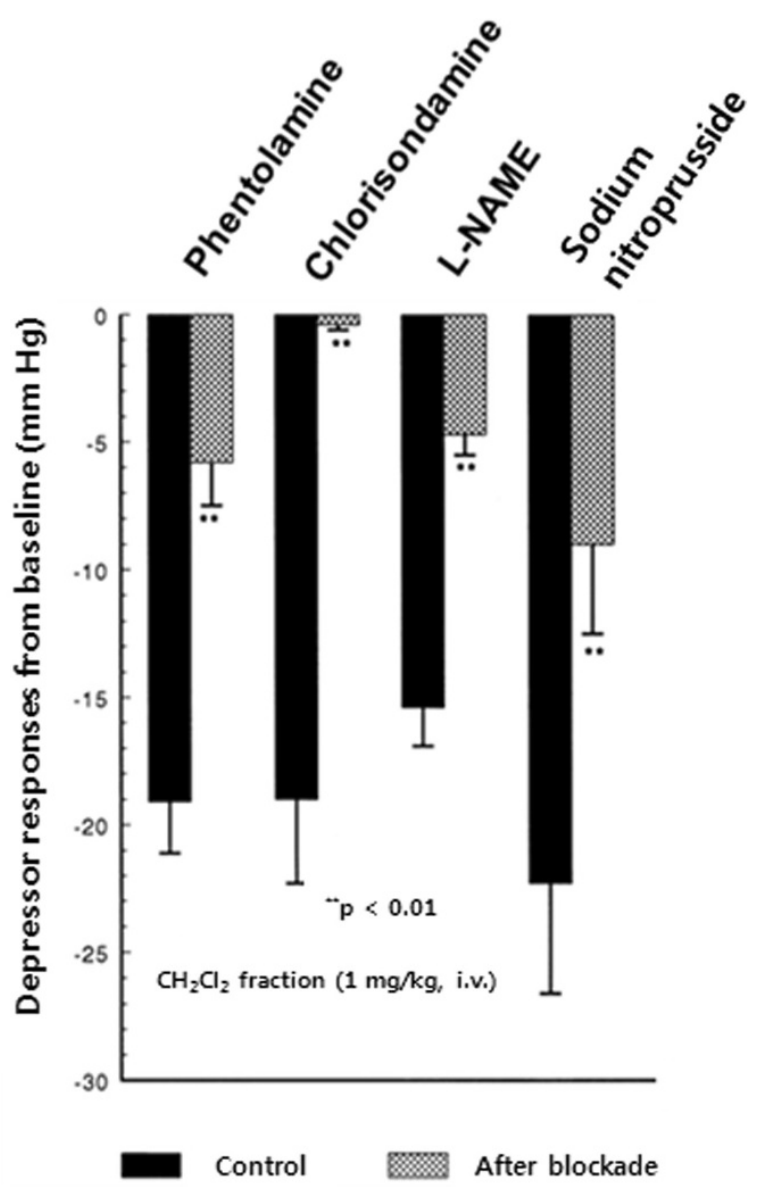

Figure 6 Influence of phentolamine, chlorisondamine, 3-[(3-cholamidopropyl) dimethylammonio]-1-propane sulfonate (L-NAME), and nitroprusside on methylene chloride $\left(\mathrm{CH}_{2} \mathrm{Cl}_{2}\right)$ fraction-induced hypotensive action in the anesthetized rats. Phentolamine $(1 \mathrm{mg} / \mathrm{kg})$, chlorisondamine (1 mg/kg), L-NAME (3 mg/kg/30 min), and sodium nitroprusside (30 $\mathrm{mg} / \mathrm{kg} / 30 \mathrm{~min}$ ) were given intravenously (i.v.), respectively, after obtaining $\mathrm{CH}_{2} \mathrm{Cl}_{2}$ fraction-induced hypotensive action. Statistical difference was analyzed by comparing control response with that after treatment with each blockade. ${ }^{* *} p<0.01$.

through the increased NO production due to the activation of NO synthase [1,14]. In the present study, the $\mathrm{CH}_{2} \mathrm{Cl}_{2}$ fraction elicited a concentration-dependent inhibition in phenylephrine-induced contractile responses of rat aortic rings with a functional endothelium. This effect was greatly abolished in the absence of a functional endothelium by treatment with CHAPS, which is a detergent for the removal of endothelium, indicating that the vasodilator effect of the $\mathrm{CH}_{2} \mathrm{Cl}_{2}$ fraction is dependent on endothelium-derived relaxing factors. To evaluate the participation of $\mathrm{NO}$ in the vasorelaxant activity of the $\mathrm{CH}_{2} \mathrm{Cl}_{2}$ fraction, aortic rings were also treated with L-NAME, a classical $\mathrm{NO}$ synthase inhibitor. In the present experimental condition, the $\mathrm{CH}_{2} \mathrm{Cl}_{2}$ fraction-induced vasodilatation was markedly blocked, as similarly observed in endotheliumdenuded aortic rings by CHAPS, suggesting that NO is the main endothelium-derived relaxing factor involved in $\mathrm{CH}_{2} \mathrm{Cl}_{2}$ fraction activity. The present results are fully in accordance with previous findings obtained from red wines and grapes. Previously, it has been reported that red wines and grapes exhibit endothelium-dependent relaxation of blood vessels via enhanced generation and/or increased biological activity of NO, leading to the elevation of cGMP levels $[6,7,15,16]$. In vivo, the polyphenol compounds of red wine (PCRW) were shown to reduce blood pressure in normotensive and hypertensive rats [17-19]. In denuded aortic rings, a PCRW concentration 103-fold higher was necessary to induce relaxation $[20,21]$. Besides NO, red wine affected the formation of other mediators of vascular tone, such as endothelium-derived hyperpolarizing factor [20] and prostacyclin [22]. The mechanisms underlining NO-dependent vasorelaxation caused by PCRW were investigated $[6,8,23]$. In addition to the increased NO synthase activity, PCRW may prolong the half-life and increase the bioavailability of $\mathrm{NO}$, by reducing its degradation mediated by reactive oxygen species [24]. It has also been shown that Provinol elicited endothelium-dependent relaxation of rat femoral artery by the $\mathrm{Ca}^{2+}$-induced increase of $\mathrm{NO}$ 


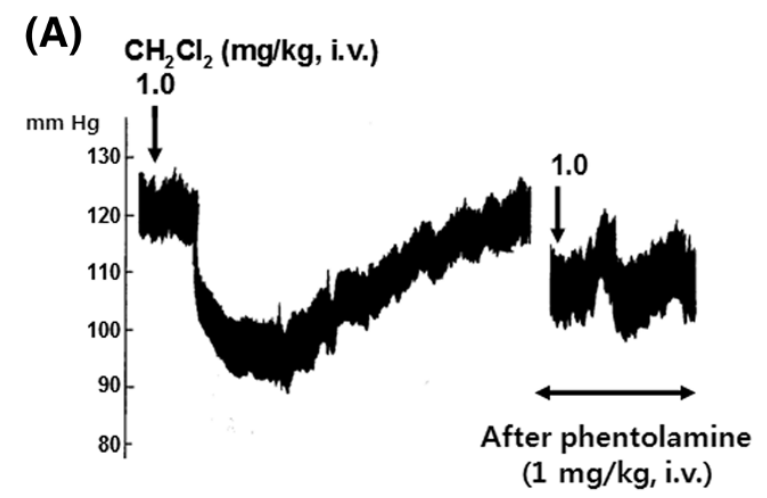

(B)

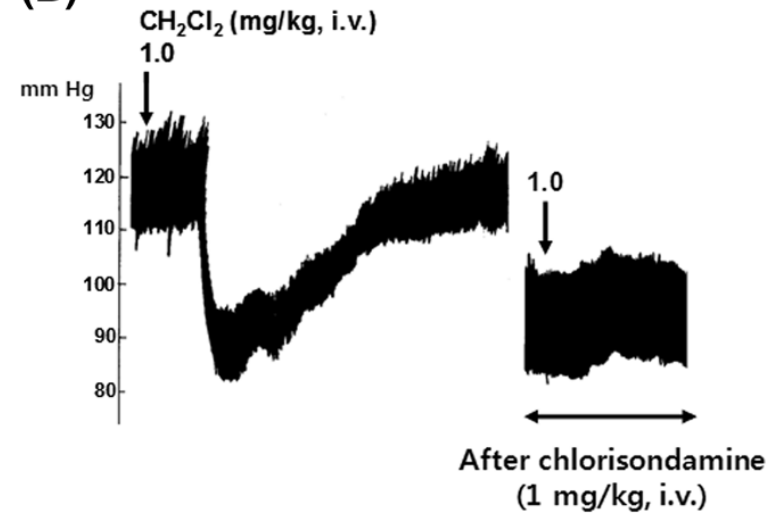

Figure 7 A typical tracing showing the effects of (A) phentolamine and (B) chlorisondamine on the hypotensive action of methylene chloride $\left(\mathrm{CH}_{2} \mathrm{Cl}_{2}\right)$ fraction in the anesthetized rats. Phentolamine $(1 \mathrm{mg} / \mathrm{kg})$ and chlorisondamine ( $1 \mathrm{mg} / \mathrm{kg}$ ) were given intravenously after obtaining control hypotensive responses of $\mathrm{CH} 2 \mathrm{Cl} 2$ fraction, respectively. i.v., intravenously.

synthase activity and by protecting NO from degradation [6]. Yu et al. [2] have found that PCRW inhibits the CA secretory responses evoked by stimulation of cholinergic (both muscarinic and nicotinic) receptors as well as by direct membrane depolarization from the isolated perfused adrenal gland of the normotensive rats. It seems that this inhibitory effect of PCRW is mediated by blocking the influx of both ions through $\mathrm{Na}^{+}$and $\mathrm{Ca}^{2+}$ channels into the rat adrenomedullary chromaffin cells as well as by inhibiting the release of $\mathrm{Ca}^{2+}$ from the cytoplasmic calcium store, which are due at least partly to the increased NO production through the activation of $\mathrm{NO}$ synthase.

Generally, endothelium-derived NO plays an important role in the control of vascular homeostasis. NO modulates vascular tone and growth of vascular smooth muscle cells and decreases platelet adhesion and aggregation. It also decreases the adherence of other blood components $[5,25]$. A decrease in NO production or bioavailability is closely associated with endothelial dysfunction or injury, which is an important factor in pathologies such as atherosclerosis, restenosis, and hypertension [26]. PCRW and a grape skin

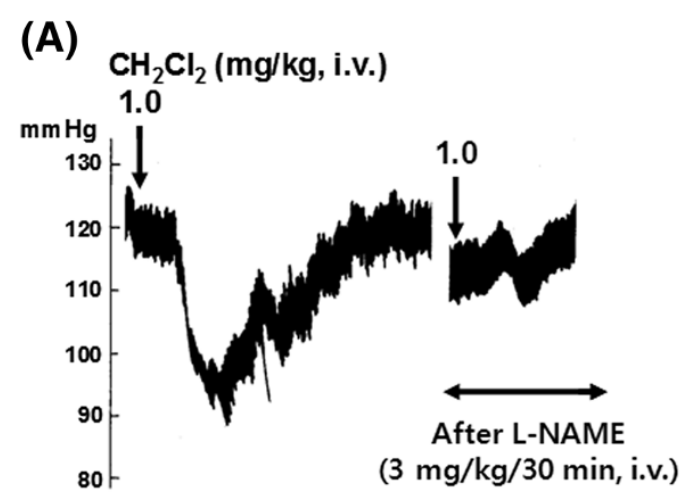

(B)
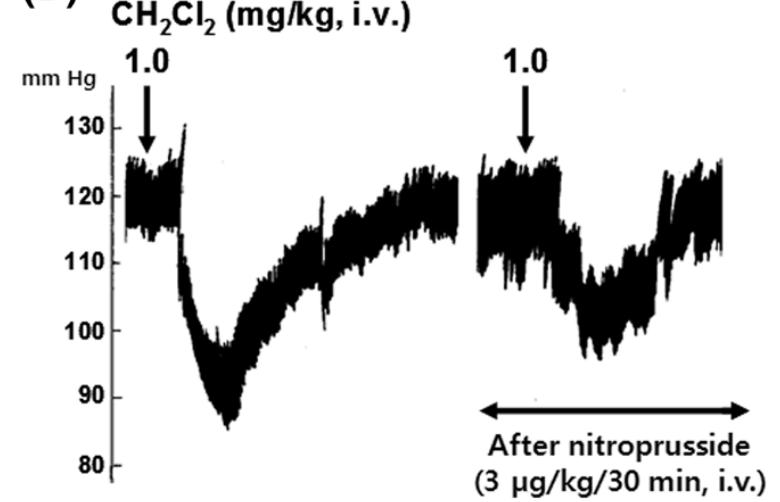

Figure 8 A typical tracing showing the effects of $(A) N^{\omega}$-nitro-Larginine methyl ester hydrochloride (L-NAME) and (B) nitroprusside on the hypotensive action of methylene chloride $\left(\mathrm{CH}_{2} \mathrm{Cl}_{2}\right)$ fraction in the anesthetized rats. L-NAME (3 mg/kg/30 min) and nitroprusside (30 $\mu \mathrm{g} / \mathrm{kg} / 30 \mathrm{~min})$ were given intravenously after obtaining control hypotensive responses of $\mathrm{CH}_{2} \mathrm{Cl}_{2}$ fraction, respectively. i.v., intravenously.

extract also reduced blood pressure in males in several models of experimental hypertension [19,27-30], which was related to a combination of vasodilator and antioxidant actions. Pechanova and his colleagues [27] also provided evidence that Provinol partially prevents L-NAME-induced hypertension, cardiovascular remodeling, and vascular dysfunction via the increase of NO synthase activity and prevention of oxidative stress. In the present study, the intravenous $\mathrm{CH}_{2} \mathrm{Cl}_{2}$ fraction-induced hypotensive response was significantly inhibited by pretreatment with L-NAME or sodium nitroprusside. In light of these results, it seems that the $\mathrm{CH}_{2} \mathrm{Cl}_{2}$ fraction may produce hypotensive action at least through the increased NO production by eNOS activation. Thus, in view of the beneficial effects of plant polyphenols, the present results of the $\mathrm{CH}_{2} \mathrm{Cl}_{2}$ fraction should shed light on the fact that the unique components of the $\mathrm{CH}_{2} \mathrm{Cl}_{2}$ fraction may contribute to the treatment or prevention of hypertension through their complex influence on the NO balance in the cardiovascular system. 


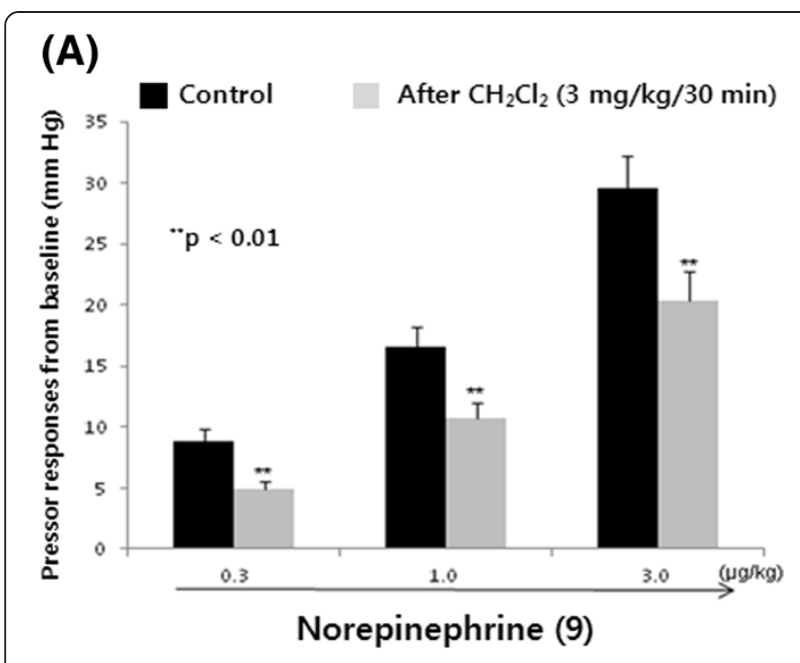

(B)

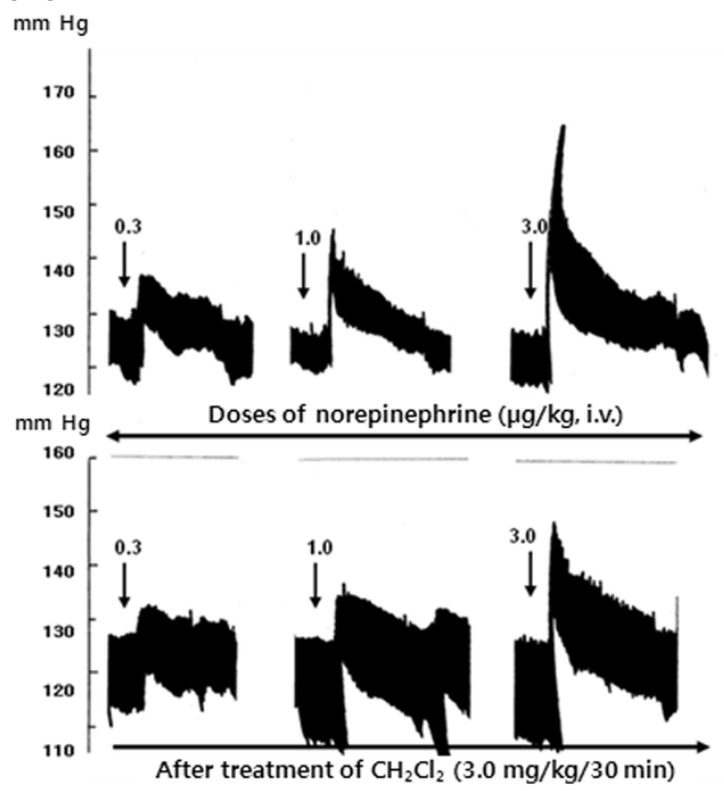

Figure 9 (A) Influence of intravenous methylene chloride $\left(\mathrm{CH}_{2} \mathrm{Cl}_{2}\right)$ fraction on norepinephrine (NE)-evoked pressor responses and (B) the representative tracing of effect of $\mathrm{CH}_{2} \mathrm{Cl}_{2}$ fraction on intravenous $\mathrm{NE}$-induced pressor responses in anesthetized rats. $\mathrm{CH}_{2} \mathrm{Cl} 2$ fraction $(3.0 \mathrm{mg} / \mathrm{kg} / 30 \mathrm{~min}$ ) was given intravenously after obtaining the corresponding control responses of intravenous NE (0.3, 1.0 , and $3.0 \mu \mathrm{g} / \mathrm{kg}$, respectively). ${ }^{* *} p<0.01$. At arrow marks, the indicated doses $(0.3,1.0$, and $3.0 \mu \mathrm{g} / \mathrm{kg}$ ) of NE were administered into a femoral vein. (A) NE-induced hypertensive responses in a non-treated rat. (B) $\mathrm{NE}$-induced hypertensive responses in a $\mathrm{CH}_{2} \mathrm{Cl}_{2}$ fraction-pretreated rat. $\mathrm{CH}_{2} \mathrm{Cl}_{2}$ fraction was infused into a femoral vein with a rate of $3 \mathrm{mg} / \mathrm{kg} /$ $30 \mathrm{~min}$. Arterial blood pressure from preinjection level was expressed in -mmHg. The chart speed was $10 \mathrm{~mm} / \mathrm{min}$. i.v., intravenously.

Generally, it is well known that potassium chloride $(\mathrm{KCl})$ opens voltage-dependent calcium channels by depolarizing the cell membrane of vascular smooth muscle, resulting in increased influx of extracellular $\mathrm{Ca}^{2+}$ [31-34]. Kim et al. [35] have shown that the contractile responses of vascular smooth muscle induced by $\mathrm{CaCl}_{2}$ and $\mathrm{KCl}$ may result most likely from the increased influx of extracellular $\mathrm{Ca}^{2+}$ through the voltage-dependent calcium channels (VDCCs). VDCCs are activated by depolarization of the plasma membrane when the extracellular $\mathrm{K}^{+}$concentration is increased. In the present work, incubation with the $\mathrm{CH}_{2} \mathrm{Cl}_{2}$ fraction inhibited $\mathrm{KCl}$ concentration-dependent contractile response in rat aortic strips. This result is consistent with the effect of $17-\beta$ estradiol on a large elastic aorta as in previous reports [36,37] and is also supported by another study [38]. These findings suggest that the $\mathrm{CH}_{2} \mathrm{Cl}_{2}$ fraction may have $\mathrm{Ca}^{2+}$ antagonistic properties and can inhibit extracellular $\mathrm{Ca}^{2+}$ influx through VDCCs, which are similar to those of $17-\beta$ estradiol or resveratrol. Generally, the mechanism of potassium-induced vasoconstriction has been shown to be through the calcium influx by the opening of the VDCCs [39,40]. VDCC blockers such as nifedipine or verapamil have been reported to attenuate potassium-induced vasoconstriction [41,42]. The contractile activity of vascular smooth muscle cells is mainly regulated by control over the cytoplasmic calcium concentration and both intracellular and extracellular calcium pools $[42,43]$. Based on these findings, the present results that the $\mathrm{CH}_{2} \mathrm{Cl}_{2}$ fraction inhibited high $\mathrm{K}^{+}$-evoked contractile responses and that the inhibitory effect of the $\mathrm{CH}_{2} \mathrm{Cl}_{2}$ fraction on high $\mathrm{K}^{+}$-evoked contractile responses was enhanced, although their data are not shown here, indicate that the $\mathrm{CH}_{2} \mathrm{Cl}_{2}$ fraction may block the VDCCs in aortic smooth muscle cells.

In the present study, the finding that $\mathrm{CH}_{2} \mathrm{Cl}_{2}$ fractioninduced hypotension is suppressed by the pretreatment with an autonomic ganglionic blocker (chlorisondamine) and adrenergic $\alpha$-blocker (phentolamine) suggests strongly that the $\mathrm{CH}_{2} \mathrm{Cl}_{2}$ fraction-induced hypotension may be mediated through the inhibition of sympathetic tone. The action site of the $\mathrm{CH}_{2} \mathrm{Cl}_{2}$ fraction seems to be the sympathetic ganglia a higher level because its hypotensive response is inhibited by prior treatment of chlorisondamine. Furthermore, in terms of the fact that intravenous $\mathrm{CH}_{2} \mathrm{Cl}_{2}$ fraction-evoked hypotension is significantly attenuated by adrenergic $\alpha$-receptor blockade (phentolamine) and that the $\mathrm{CH}_{2} \mathrm{Cl}_{2}$ fraction inhibits greatly the pressor responses of norepinephrine, it is considered that the $\mathrm{CH}_{2} \mathrm{Cl}_{2}$ fraction causes the hypotensive action via the blockade of adrenergic $\alpha_{1}$-receptors. Among drugs which interfere with peripheral sympathetic function, adrenergic $\alpha$-receptor blocking agents alone cause reversal of the epinephrine pressor response [44]. When epinephrine is administered to untreated animals, its $\alpha$-agonist properties predominate, resulting in a rise in mean arterial pressure. However, in the presence of adrenergic $\alpha$-receptor blockade, the peripheral $\beta_{2}$-agonist properties of epinephrine predominate and a fall 
in arterial pressure or reversal of the pressor response is observed. In contrast, the pressor responses to norepinephrine are impaired by adrenergic $\alpha$-receptor blockade but are not reversed [45] as this agent possesses little $\beta_{2}$ agonist activity [46]. These previous facts support that $\mathrm{CH}_{2} \mathrm{Cl}_{2}$ fraction-induced depressor action is due to the blockade of adrenergic $\alpha$-receptors in the periphery. In the present work, the $\mathrm{CH}_{2} \mathrm{Cl}_{2}$ fraction also inhibited the norepinephrine-induced pressor responses as well as PEevoked contractile responses in aortic strips isolated from normotensive rats. These results suggest that the $\mathrm{CH}_{2} \mathrm{Cl}_{2}$ fraction may elicit the antagonistic activity of adrenergic $\alpha_{1}$-receptors.

Based on all these results, many studies strongly support the view that a polyphenol-rich diet, such as Rubus coreanum and red wine, could improve endothelial function and that the mechanisms of this beneficial effect found in the above-discussed in vitro studies (especially increased NO) might be involved in vivo, both in patients and in animals.

\section{Conclusion}

In conclusion, the present study provides conclusive data showing for the first time that the $\mathrm{CH}_{2} \mathrm{Cl}_{2}$ fraction elicits endothelium- and NO-dependent vasorelaxation, which are due to the unique polyphenolic constituents of the $\mathrm{CH}_{2} \mathrm{Cl}_{2}$ fraction that may augment eNOS activity, and thus facilitates endothelial $\mathrm{NO}$ output, and suggesting that the $\mathrm{CH}_{2} \mathrm{Cl}_{2}$ fraction might be helpful in treating or alleviating cardiovascular diseases, such as hypertension and angina pectoris. The identification of the responsible constituents should help in the design of strategies to prevent or to improve cardiovascular diseases.

\section{Abbreviations \\ $\mathrm{CH}_{2} \mathrm{Cl}_{2}$ fraction: Methylene chloride $\left(\mathrm{CH}_{2} \mathrm{Cl}_{2}\right)$ fraction; EtOAC \\ fraction: Ethylacetate fraction; $\mathrm{BuOH}$ fraction: N-butanol fraction; PE: Phenylephrine; NO: Nitric oxide; PCRC: Polyphenol compounds isolated from Rubus coreanum MIQUEL; CA: Catecholamines; CHAPS: 3-[(3- cholamidopropyl) dimethylammonio]-1-propane sulfonate; DMSO: Dimethyl sulfoxide; L-NAME: $\mathrm{N}^{\omega}$-nitro-L-arginine methyl ester hydrochloride; VDCCs: Voltage-dependent calcium channels.}

\section{Competing interests}

The authors declare that they have no competing interests.

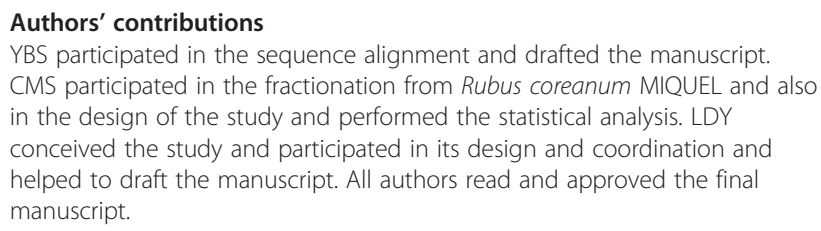

\section{Acknowledgements}

This study was supported partly by a research grant from Chosun University, Gwangju, Korea (2010-2011)

\section{Author details}

${ }^{1}$ Department of Anesthesiology and Pain Medicine, School of Medicine, Chosun University, Gwangju, Korea. ${ }^{2}$ Department of Leisure and Sport, College of Public Health and Welfare, Dongshin University, Naju, Korea.
${ }^{3}$ Department of Pharmacology, School of Medicine, Chosun University, 309 Pilmun-daero, Dong-gu, Gwangju 501-759, Korea.

Received: 10 November 2014 Accepted: 10 November 2014 Published online: 25 November 2014

\section{References}

1. Kee YW, Lim DY: Influence of polyphenolic compounds isolated from Rubus coreanum on catecholamine release in the rat adrenal medulla. Arch Pharm Res 2007, 30:1240-1251.

2. Yu BS, Ko WS, Lim DY: Inhibitory mechanism of polyphenol compounds isolated from red wine on catecholamine release in the perfused rat adrenal medulla. Biomol Ther 2008, 16:147-160.

3. Palmer RM, Ferrige AG, Moncada S: Nitric oxide release accounts for the biological activity of endothelium-derived relaxing factor. Nature 1987, 327:524-526.

4. Radomski MW, Palmer RM, Moncada S: Endogenous nitric oxide inhibits human platelet adhesion to vascular endothelium. Lancet 1987, 2:1057-1058.

5. Moncada S, Palmer RM, Higgs EA: Nitric oxide: physiology, pathophysiology, and pharmacology. Pharmacol Rev 1991, 43:109-142.

6. Zenebe W, Pechanova O, Andriantsitohaina R: Red wine polyphenols induce vasorelaxation by increased nitric oxide bioactivity. Physiol Res 2003, 52:425-432.

7. Fitzpatrick DF, Hirschfield SL, Coffey RG: Endothelium-dependent vasorelaxing activity of wine and other grape products. Am J Physio 1993, 265(2 Pt 2):H774-H778.

8. Andriambeloson E, Stoclet JC, Andriantsitohaina R: Mechanism of endothelial nitric oxide-dependent vasorelaxation induced by wine polyphenols in rat thoracic aorta. J Cardiovasc Pharmacol 1999, 33:248-254.

9. Bouloumie A, Bauersachs J, Linz W, Scholkens BA, Wiemer G, Fleming I, Busse R: Endothelial dysfunction coincides with an enhanced nitric oxide synthase expression and superoxide anion production. Hypertension 1997, 30:934-941.

10. Moore PK, al-Swayeh OA, Chong NW, Evans RA, Gibson A: L-NG-nitro arginine (L-NOARG), a novel, L-arginine-reversible inhibitor of endotheliumdependent vasodilatation in vitro. Br J Pharmacol 1990, 99:408-412.

11. Tallarida RJ, Murray RB: Manual of Pharmacologic Calculation with Computer Programs. 2nd edition. New York: Springer-Verlag; 1987.

12. Lim HJ, Min SY, Woo ER, Lim DY: Inhibitory effects of polyphenol-rich fraction extracted from Rubus coreanum M on thoracic aortic contractility of spontaneously hypertensive rats. Biomol Ther 2011, 19:477-486.

13. Wada A, Takara H, Izumi F, Kobayashi H, Yanagihara N: Influx of 22Na through acetylcholine receptor-associated $\mathrm{Na}$ channels: relationship between 22Na influx, 45Ca influx and secretion of catecholamines in cultured bovine adrenal medulla cells. Neuroscience 1985, 15:283-292.

14. Lim DY, Hong SP: Inhibitory mechanism of polyphenols isolated from Rubus coreanum on catecholamine secretion from the adrenal medulla of SHRs. In Proceedings of the 6th Asian-Pacific Congress of Hypertension; 2007 Nov 16-19; Beijing, China, APCH 2007 abstract book. Edited by Asia Pacific Society for Hypertension. Beijing: Asia Pacific Society for Hypertension; 2007.

15. Fitzpatrick DF, Hirschfield SL, Ricci T, Jantzen P, Coffey RG: Endotheliumdependent vasorelaxation caused by various plant extracts. J Cardiovasc Pharmacol 1995, 26:90-95.

16. Fitzpatrick DF, Fleming RC, Bing B, Maggi DA, O'Malley RM: Isolation and characterization of endothelium-dependent vasorelaxing compounds from grape seeds. J Agric Food Chem 2000, 48:6384-6390.

17. Mizutani K, Ikeda K, Kawai Y, Yamori Y: Extract of wine phenolics improves aortic biomechanical properties in stroke-prone spontaneously hypertensive rats (SHRSP). J Nutr Sci Vitaminol (Tokyo) 1999, 45:95-106.

18. Diebolt M, Bucher B, Andriantsitohaina R: Wine polyphenols decrease blood pressure, improve NO vasodilatation, and induce gene expression. Hypertension 2001, 38:159-165.

19. Bernatova I, Pechanova O, Babal P, Kysela S, Stvrtina S, Andriantsitohaina R: Wine polyphenols improve cardiovascular remodeling and vascular function in NO-deficient hypertension. Am J Physiol Heart Circ Physiol 2002, 282:H942-H948.

20. Ndiaye M, Chataigneau T, Andriantsitohaina R, Stoclet JC, Schini-Kerth VB: Red wine polyphenols cause endothelium-dependent EDHF-mediated 
relaxations in porcine coronary arteries via a redox-sensitive mechanism. Biochem Biophys Res Commun 2003, 310:371-377.

21. Corder R, Douthwaite JA, Lees DM, Khan NQ, Viseu Dos Santos AC, Wood EG, Carrier MJ: Endothelin-1 synthesis reduced by red wine. Nature 2001, 414:863-864.

22. Schramm DD, Pearson DA, German JB: Endothelial cell basal PGI2 release is stimulated by wine in vitro: one mechanism that may mediate the vasoprotective effects of wine. J Nutr Biochem 1997, 8:647-651.

23. Martin S, Andriambeloson E, Takeda K, Andriantsitohaina R: Red wine polyphenols increase calcium in bovine aortic endothelial cells: a basis to elucidate signalling pathways leading to nitric oxide production. $\mathrm{Br} J$ Pharmacol 2002, 135:1579-1587.

24. De Gaetano G, Cerletti C, European project: FAIR CT 973261 project participants: wine and cardiovascular disease. Nutr Metab Cardiovasc Dis 2001, 11 (4 Suppl):47-50

25. Scott-Burden T, Vanhoutte PM: Regulation of smooth muscle cell growth by endothelium-derived factors. Tex Heart Inst J 1994, 21:91-97.

26. Landmesser $\mathrm{U}$, Drexler $\mathrm{H}$ : Endothelial function and hypertension. Curr Opin Cardiol 2007, 22:316-320.

27. Pechanova O, Bernatova I, Babal P, Martinez MC, Kysela S, Stvrtina S, Andriantsitohaina R: Red wine polyphenols prevent cardiovascular alterations in L-NAME-induced hypertension. J Hypertens 2004 22:1551-1559.

28. Sarr M, Chataigneau M, Martins S, Schott C, El Bedoui J, Oak MH, Muller B, Chataigneau T, Schini-Kerth VB: Red wine polyphenols prevent angiotensin II-induced hypertension and endothelial dysfunction in rats: role of NADPH oxidase. Cardiovasc Res 2006, 71:794-802.

29. Soares De Moura R, Costa Viana FS, Souza MA, Kovary K, Guedes DC, Oliveira EP, Rubenich LM, Carvalho LC, Oliveira RM, Tano T, Gusmão Correia $\mathrm{ML}$ : Antihypertensive, vasodilator and antioxidant effects of a vinifera grape skin extract. J Pharm Pharmacol 2002, 54:1515-1520.

30. Jimenez R, Lopez-Sepulveda R, Kadmiri M, Romero M, Vera R, Sanchez M, Vargas F, OValle F, Zarzuelo A, Dueñas M, Santos-Buelga C, Duarte J: Polyphenols restore endothelial function in DOCA-salt hypertension: role of endothelin-1 and NADPH oxidase. Free Radic Biol Med 2007, 43:462-473.

31. Bolton TB: Mechanisms of action of transmitters and other substances on smooth muscle. Physiol Rev 1979, 59:606-718.

32. Schwartz A, Taira N: Calcium channel-blocking drugs: a novel intervention for the treatment of cardiac disease. Proceedings of the Symposium on Calcium Blocking Agents. July 25-26, 1981, Tokyo, Japan. Circ Res 1983, 52(2 Pt 2):11-|181.

33. Dube GP, Baik YH, Schwartz A: Effects of a novel calcium channel agonist dihydropyridine analogue, Bay k 8644, on pig coronary artery: biphasic mechanical response and paradoxical potentiation of contraction by diltiazem and nimodipine. J Cardiovasc Pharmacol 1985, 7:377-389.

34. Dube GP, Baik YH, Van Breemen C, Schwartz A: Effects of isosorbide dinitrate and diltiazem on $\mathrm{Ca} 2+$ flux and contraction in artery. Eur $\mathrm{J}$ Pharmacol 1988, 145:39-47.

35. Kim JM, Park KO, Baik YH: Effects of antiepileptic drugs on contractile responses of vascular smooth muscles. Chonnam J Med Sci 1989, 2:50-59.

36. Li HF, Li W, Zheng TZ, Qu SY, Zhang CL: A study of the mechanisms involved in relaxation induced by 17 -beta-estradiol in the isolated rabbit aorta. Arch Gynecol Obstet 2002, 266:101-104.

37. Li HF, Tian ZF, Qiu XQ, Wu JX, Zhang P, Jia ZJ: A study of mechanisms involved in vasodilatation induced by resveratrol in isolated porcine coronary artery. Physiol Res 2006, 55:365-372.

38. Nevala R, Korpela R, Vapaatalo H: Plant derived estrogens relax rat mesenteric artery in vitro. Life Sci 1998, 63:PL95-PL100.

39. Spedding $M$, Paoletti R: Classification of calcium channels and the sites of action of drugs modifying channel function. Pharmacol Rev 1992, 44:363-376

40. Ryman T, Brandt $L$, Andersson KE, Mellergard P: Regional and species differences in vascular reactivity to extracellular potassium. Acta Physiol Scand 1989, 136:151-159.

41. Cortijo J, Perpina M, Esplugues J, Morcillo EJ: Pharmacological characterization of the effects of verapamil and nifedipine on isolated guinea-pig lung parenchymal strip. Gen Pharmacol 1986, 17:211-217

42. Triggle DJ, Zheng W, Hawthorn M, Kwon YW, Wei XY, Joslyn A, Ferrante J, Triggle AM: Calcium channels in smooth muscle: properties and regulation. Ann N Y Acad Sci 1989, 560:215-229.
43. Johns A, Leijten P, Yamamoto H, Hwang K, van Breemen C: Calcium regulation in vascular smooth muscle contractility. Am J Cardiol 1987, 59:18A-23A.

44. Constantine JW, Mcshane WK, Scriabine A, Hess HJ: Analysis of the hypotensive action of prazosin. In Hypertension: Mechanisms and Management. Edited by Onesti G, Kim KE, Moyer JH. New York: Grume \& Stratton Inc; 1973.

45. Freis ED, Mackay JC, Oliver WF: The effect of sympatholytic drugs on the cardiovascular responses to epinephrine and norepinephrine in man. Circulation 1951, 3:254-259.

46. Ablad B, Borg KO, Carlsson E, EK L, Johnson G, Malmfors T, Regårdh CG: A survey of the pharmacological properties of metoprolol in animals and man. Acta Pharmacol Toxicol (Copenh) 1975, 36(Suppl 5):7-23.

doi:10.1186/s40885-014-0006-1

Cite this article as: Yu et al:: Depressor action and vasorelaxation of methylene chloride fraction extracted from Rubus coreanum. Clinical Hypertension 2014 20:6.

\section{Submit your next manuscript to BioMed Central and take full advantage of:}

- Convenient online submission

- Thorough peer review

- No space constraints or color figure charges

- Immediate publication on acceptance

- Inclusion in PubMed, CAS, Scopus and Google Scholar

- Research which is freely available for redistribution
C Biomed Central 